\title{
Quantitative Determining of Ultra-Trace Aluminum Ion in Environmental Samples by Liquid Phase Microextraction Assisted Anodic Stripping Voltammetry
}

\author{
Liuyang Zhang ${ }^{1,+}$, Jinju Luo ${ }^{1,+}$, Xinyu Shen ${ }^{2}$, Chunya Li ${ }^{1}$, Xian Wang ${ }^{1}$, Bei Nie ${ }^{1}$ \\ and Huaifang Fang ${ }^{1, *}$ \\ 1 Key Laboratory of Analytical Chemistry of the State Ethnic Affairs Commission, \\ College of Chemistry and Materials Science, South-Central University for Nationalities, \\ Wuhan 430074, China; zlyzly1239@163.com (L.Z.); JinjuLuo@163.com (J.L.); lichychem@163.com (C.L.); \\ xwang27@hotmail.com (X.W.); bnie@cigit.ac.cn (B.N.) \\ 2 Key Laboratory of Analytical Chemistry for Biology and Medicine, Wuhan University, \\ Ministry of Education, Wuhan 430072, China; shenxy@whu.edu.cn \\ * Correspondence: hffang@mail.scuec.edu.cn; Tel.: +86-135-1729-5825 \\ + These authors contributed equally to this work.
}

Received: 31 March 2018; Accepted: 6 May 2018; Published: 10 May 2018

\begin{abstract}
Direct detecting of trace amount $\mathrm{Al}(\mathrm{III})$ in aqueous solution by stripping voltammetry is often frustrated by its irreversible reduction, resided at $-1.75 \mathrm{~V}$ (vs. $\mathrm{Ag} / \mathrm{AgCl}$ reference), which is in a proximal potential of proton reduction. Here, we described an electroanalytical approach, combined with liquid phase microextraction (LPME) using ionic liquid (IL), to quantitatively assess trace amount aluminum in environmental samples. The $\mathrm{Al}(\mathrm{III})$ was caged by 8 -hydroxyquinoline, forming a superb hydrophobic metal-chelate, which sequentially transfers and concentrates in the bottom layer of IL-phase during LPME. The preconcentrated Al(III) was further analyzed by a square-wave anodic stripping voltammetry (SW-ASV). The resulting Al-deposited electrodes were characterized by scanning electron microscopy and powder X-ray diffraction, showing the intriguing amorphous nanostructures. The method developed provides a linear calibration ranging from 0.1 to $1.2 \mathrm{ng} \mathrm{L}^{-1}$ with a correlation coefficient of 0.9978 . The LOD attains as low as $1 \mathrm{pmol} \mathrm{L}^{-1}$, which reaches the lowest report for $\mathrm{Al}$ (III) detection using electroanalytical techniques. The applicable methodology was implemented for monitoring $\mathrm{Al}(\mathrm{III})$ in commercial distilled water.
\end{abstract}

Keywords: ionic liquid; liquid phase microextraction; anodic stripping voltammetry; aluminum ion

\section{Introduction}

Spectrometric techniques, such as atomic absorption spectrometry [1], inductively coupled plasma atomic emission spectrometry [2], fluorometry [3], and inductively coupled plasma-mass spectrometry (ICP-MS) [4], are widely applied in detecting metals in aqueous samples. Alternatively, electroanalytical techniques offer important advantages, such as good sensitivity, high selectivity, cost-effective, easy for automation and suitable for portable devices $[5,6]$. However, in aqueous solutions, direct voltammetric determination of metal ions with high electronegativity, such as aluminum, potassium, sodium and barium, is limited due to the parallel hydrogen evolution reaction.

Polarographic determination of $\mathrm{Al}(\mathrm{III})$ was achieved by reducing aluminum di-o-hydroxyazo complex [7]. Codeposition with $\mathrm{Zn}^{2+}$ on screen-printed carbon electrode prior to differential-pulse anodic stripping voltammetry (ASV) was also adopted [8]. However, the sensitivities of these methods 
remain poor. The voltammetric response of an electroactive ligand that forms a complex with $\mathrm{Al}(\mathrm{III})$ were changed in the presence of $\mathrm{Al}(\mathrm{III})$, which provides an indirect electrochemical strategy for the determination of $\mathrm{Al}(\mathrm{III})$ [9-41]. There also are a few biosensors developed for $\mathrm{Al}(\mathrm{III})$ [42-44]. Among these reports, the lowest detection limit was $8 \mathrm{pmol} \mathrm{L}^{-1}$ of $\mathrm{Al}(\mathrm{III})$, using electrochemical impedance spectroscopy [45].

Many ionic liquids have the following unique physical properties: wide electrochemical windows, high thermal and chemical stability, negligible vapor pressure, good extractabilities for various organic compounds and metal ions, and high conductivities compared to non-aqueous solvents. Because of these characteristics, ILs are employed in multiple fields such as batteries [46], fuel cells [47], electrochemistry [48], catalysis [49], synthesis [50] and electroplating [51]. In addition, several methods, combining extraction using ionic liquid with suitable analytical methods, have been developed to determine trace and sub-trace levels of metal ions [52-56]. Due to the high viscosity of ILs, diluting with organic solvents or back-extraction should be taken prior to analysis [52]. For back-extraction, several acidic and basic solutions have been used as stripping medium. This additional step is usually time-consuming, and also a potential source of contamination, which limits its wide utilization.

IL-based liquid-liquid extraction (LLE) combined with electrochemistry was first reported by Hussey group: the $\mathrm{Cs}^{+}$and $\mathrm{Sr}^{2+}$ in aqueous samples were selective extracted into ionic liquid and was analyzed at a mercury film electrode [57]. The IL-based LLE coupled with ASV to determine $\mathrm{Pb}(\mathrm{II})$ and $\mathrm{Cd}(\mathrm{II})$ was also reported by Nagaosa [58]. The extraction of $\mathrm{Pb}$ using IL followed by differential pulse ASV on a boron-doped diamond microcell was presented by Jaffrezic-Renault et al. [59]. The calibration curves for $\mathrm{Pb}$ are in the range of $0-4 \mu \mathrm{g} \mathrm{L}-1$, with a LOD of $0.3 \mu \mathrm{g} \mathrm{L}^{-1}$. Recently, Mercury was extracted with IL using temperature controlled dispersive liquid phase microextraction (LPME) and then detected by ASV [60]. Mercury was enriched by 17 times and a LOD of $0.05 \mu \mathrm{g} \mathrm{L}^{-1}$ was acquired. However, there is to date no report that IL-based LLE coupled with ASV to determine the metal ions with high electronegativity.

In the present work, an LPME-SW-ASV method has been developed for the determination of ultra-trace $\mathrm{Al}(\mathrm{III})$ in aqueous samples. In our experiments, the extraction agent was 1-octy-3methylimidazolium hexafluorophosphate $\left[\mathrm{C}_{8} \mathrm{mim}\right]\left[\mathrm{PF}_{6}\right]$, and the chelating agent was oxine. The factors influencing LPME efficiency and SW-ASV signals were systematically studied. The method developed can determine $\mathrm{Al}(\mathrm{III})$ in environmental samples with upgraded sensitivity and better selectivity, which also can be applied to determine other active metal ions.

\section{Materials and Methods}

\subsection{Reagents and Solutions}

All chemicals were of analytical reagent grade unless stated otherwise. All solutions used were prepared using ultrapure water obtained by a Milli-Q Advantage A10 system (Millipore, Bedford, MA, USA). The experiments were carried out at room temperature (approximately $25^{\circ} \mathrm{C}$ ). Stock standard solution of $\mathrm{Al}(\mathrm{III})$ were prepared by dissolving appropriate amounts of aluminum nitrate (purity $\geq 99.99 \%$, Aladdin Reagent Co., Shanghai, China) in hydrochloric acid. The samples were obtained by diluting the stock standard sample with proper solvents. 1-octy-3-methylimidazolium hexafluorophosphate $\left[\mathrm{C}_{8} \mathrm{mim}\right]\left[\mathrm{PF}_{6}\right]$ (purity $\geq 99 \%$ ) (Chengjie Chemical Reagent Co., Shanghai, China) was employed as an extracting agent without further purification. 8-hydroxyquinoline was purchased from Merck (Darmstadt, Germany). The stock solution of $10 \mathrm{mmol} \mathrm{L}^{-1}$ oxine was prepared by dissolving the appropriate amount of oxine in ethanol and was kept in refrigerator $\left(4^{\circ} \mathrm{C}\right)$ for a week. Metal solutions $\left(\mathrm{CuSO}_{4} \cdot 5 \mathrm{H}_{2} \mathrm{O}, \mathrm{MgCl}_{2} \cdot 6 \mathrm{H}_{2} \mathrm{O}, \mathrm{ZnSO}_{4}, \mathrm{Cr}\left(\mathrm{NO}_{3}\right)_{3} \cdot 9 \mathrm{H}_{2} \mathrm{O}, \mathrm{CaCl}_{2}, \mathrm{Cd}\left(\mathrm{NO}_{3}\right)_{2}\right.$ and $\mathrm{SnCl}_{2}$ (Sinopharm Chemical Reagent Co. Ltd., Shanghai, China) were used for interference experiments; $\mathrm{HNO}_{3}, \mathrm{CH}_{3} \mathrm{COOH}$ (Sinopharm Chemical Reagent Co. Ltd., Shanghai, China) were used as received; sodium acetate (purity $\geq 99.99 \%$ ) was obtained from Aladdin (Aladdin Reagent Co., Shanghai, China). 


\subsection{Instrumentation}

All electrochemical measurements were carried out using a CHI-660D electrochemical station (Chenhua Instruments Co., Shanghai, China). The peak current after a blank subtraction was used to perform linear regression. Data was processed with Origin 7.0 software. Scanning electron microscopy (SEM) images were obtained by a quanta 200 scanning electron microscopy equipped with energy dispersive spectroscopy (FEI, Hillsboro, OR, USA). The X-ray diffractograms were recorded using a Bruker D8 Advance using monochromatized Cu Ka radiation. A TGL-20B centrifuge with a $30^{\circ}$ fixed angle rotor $(\mathrm{rmin}=6.5 \mathrm{~cm}, \mathrm{rmax}=11 \mathrm{~cm})$ (Shanghai Anting Instrument Factory, Shanghai, China) was adopted to perform centrifugation. The $\mathrm{pH}$ of solution was measured with MS-H-S meter (Dragon Instrumentation Co. Ltd., Beijing, China). The three electrode system, consisting of a gold disc working electrode (O.D. $3 \mathrm{~mm}$ ), a Pt auxiliary electrode, and an $\mathrm{Ag} / \mathrm{AgCl}$ (solid) reference electrode was used. Voltammetric measurements were carried out in a microliter voltammetric cell (MVC) (Figure S1) (Supplementary Materials) in a Faraday cage. The MVC was made from polytrifluorochloroethylene. The diameter of the bottom hole was $1.2 \mathrm{~cm}$, and the diameter of the top hole (from $4 \mathrm{~mm}$ to $9 \mathrm{~mm}$ ) can be adjusted according to the volume of the extractant during LPME (from $10 \mu \mathrm{L}$ to $400 \mu \mathrm{L}$ ). As shown in Figure S1 (Supplementary Materials), the working electrode was set at the bottom of the MVC, the Pt electrode was screwed into MVC horizontally, and the $\mathrm{Ag} / \mathrm{AgCl}$ solid electrode was put into the MVC vertically. The vertical distance between Au electrode and Pt electrode was $0.5 \mathrm{~mm}$. All potentials were given with respect to the $\mathrm{Ag} / \mathrm{AgCl}$ solid electrode. To avoid accidental contamination, all sample vials and containers used were soaked in $(1+1)$ nitric acid over $24 \mathrm{~h}$, and rinsed with copious amounts of ultrapure water.

\subsection{LPME Procedures}

The $30 \mathrm{~mL}$ water samples, containing $0.246 \mathrm{~g}$ of sodium acetate, were placed into $50.0 \mathrm{~mL}$ conical-bottom polypropylene vials, and then a given amount of oxine was added as chelating agent. After mixing, the sample was placed in the dark for $20 \mathrm{~min}$ to complete the complexation. Then, a $150 \mu \mathrm{L}$ volume of $\left[\mathrm{C}_{8}\right.$ mim] $\left[\mathrm{PF}_{6}\right]$ was added into each sample vial. The $\mathrm{Al}$ (III)-oxine complex was extracted from water samples into IL phase during centrifugation (at $4500 \mathrm{rpm}$ for $10 \mathrm{~min}$ ). After extraction, the IL phase was collected, and $100 \mu \mathrm{L}$ of extractant was transferred into the MVC for the subsequent SW-ASV analysis.

\subsection{Measurement Procedure}

The gold disk electrode was polished to a mirror-like smoothness using $0.05 \mu \mathrm{m} \mathrm{Al}_{2} \mathrm{O}_{3}$ powder. It was washed successively with $1: 1(v / v) \mathrm{HNO}_{3}$, ultrapure water, ethanol and ultrapure water in an ultra-sonic bath and then dried in air. The procedures for the determination of $\mathrm{Al}(\mathrm{III})$ by SW-ASV were as follows: $100 \mu \mathrm{L}$ of extractant was transferred into the MVC. Accumulation was achieved at a given deposition potential for a fixed time. The voltammogram was recorded by applying a positive-going square-wave voltammetric potential scan from $-1.6 \mathrm{~V}$ to $0 \mathrm{~V}$ (with a frequency of $20.0 \mathrm{~Hz}$, pulse amplitude of $25.0 \mathrm{mV}$, and a step potential of $4.0 \mathrm{mV}$ ). After the measurement, a $60 \mathrm{~s}$ clean step at potential of $0.3 \mathrm{~V}$ was used to remove possible residual metals. No deaeration of solutions was needed in our SW-ASV experiments.

\subsection{Determination of Al(III) in Real Samples}

The concentration of $\mathrm{Al}(\mathrm{III})$ in Wahaha ${ }^{\circledR}$ (Hangzhou, China) pure distilled water was determined by LPME-SW-ASV. Then, $2.46 \mathrm{~g}$ of sodium acetate was dissolved in $300 \mathrm{~mL}$ of Wahaha ${ }^{\circledR}$ pure distilled water and the $\mathrm{pH}$ of solution was adjusted to 6.5 with acetic acid. A $0.3 \mathrm{~mL}$ of sample solution was introduced into $2 \mathrm{~mL}$ conical-bottom polypropylene vials, then $20 \mu \mathrm{L}$ oxine $\left(10 \mathrm{mmol} \mathrm{L}^{-1}\right.$ in ethanol) was added as chelating agent. A $150 \mu \mathrm{L}$ volume of $\left[\mathrm{C}_{8} \mathrm{mim}\right]\left[\mathrm{PF}_{6}\right]$ was added in each sample vial. In order to eliminate matrix effects, all commercial distilled water samples were analyzed 
using standard addition method. For evaluation measurements, an ICP-MS unit model NexIon300X (PerkinElmer, Richmond, CA, USA) was used.

\section{Results and Discussion}

\subsection{Electrodeposition and Characterization of the Aluminum Deposits on Gold Disk Electrode}

The stripping voltammograms of $\left[\mathrm{C}_{8} \mathrm{mim}\right]\left[\mathrm{PF}_{6}\right]$, oxine in $\left[\mathrm{C}_{8} \mathrm{mim}\right]\left[\mathrm{PF}_{6}\right]$, and the extractant of $\mathrm{Al}(\mathrm{III})$-oxine at gold disk electrode were recorded and shown in Figure 1. Noticeably, there was no appreciable peak in the stripping voltammograms of $\left[\mathrm{C}_{8} \mathrm{mim}\right]\left[\mathrm{PF}_{6}\right]$ (Figure $1 \mathrm{~A}$ ) and oxine in $\left[\mathrm{C}_{8} \mathrm{mim}\right]\left[\mathrm{PF}_{6}\right]$ (Figure 1B); the anode peak at the potential of $-1.1 \mathrm{~V}$ and $-0.8 \mathrm{~V}$ emerged for the extractant of $1 \mathrm{ng} \mathrm{L}^{-1} \mathrm{Al}(\mathrm{III})(\mathrm{C})$. These peaks should be oxidation peaks of $\mathrm{Al}$ deposits and are more positive than normal oxidation peak of $\mathrm{Al}$, which could be due to alloy formation with the Au substrate during deposition. To further verify the hypothesis, the extractant of $10 \mu \mathrm{g} \mathrm{L}^{-1} \mathrm{Al}(\mathrm{III})$ was transferred to the MVC and deposited at $-1.8 \mathrm{~V}$ for $120 \mathrm{~s}$. The SEM images and XRD analysis of the deposit are shown in Figure 2 and Supplemental Figure S2 (Supplementary Materials).

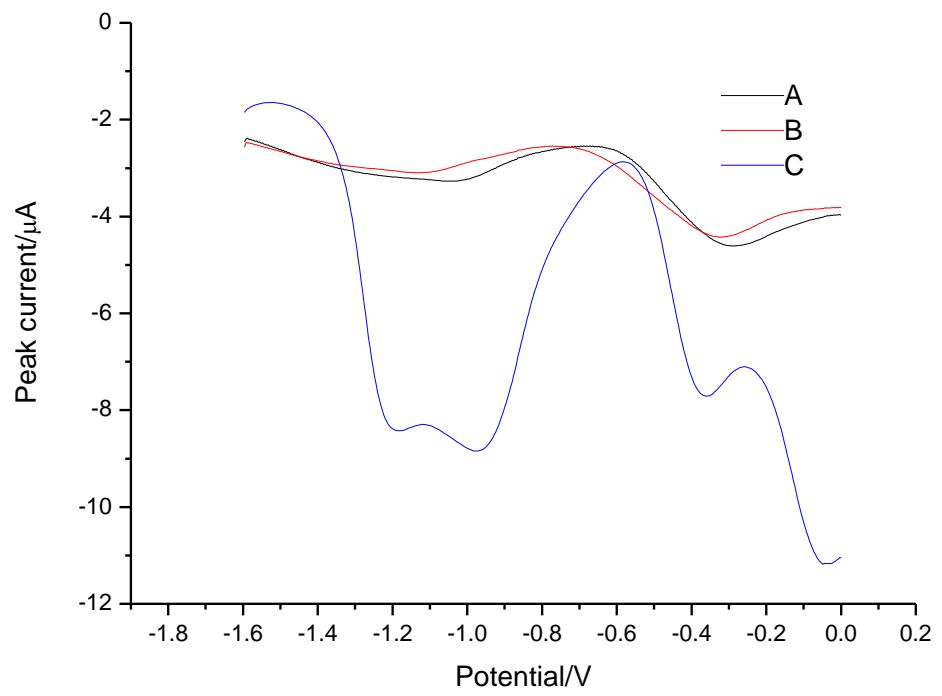

Figure 1. The square-wave anodic stripping voltammetry (SW-ASV) on gold disk electrode (GDE) at different condition: (A) $\left[\mathrm{C}_{8} \mathrm{mim}\right]\left[\mathrm{PF}_{6}\right]$; (B) oxine in $\left[\mathrm{C}_{8} \mathrm{mim}\right]\left[\mathrm{PF}_{6}\right]$; (C) IL-based liquid phase microextraction (LPME) of $0.4 \mathrm{ng} \mathrm{L}^{-1} \mathrm{Al}(\mathrm{III})$ in presence of $0.67 \mathrm{mmol} \mathrm{L}^{-1}$ oxine.
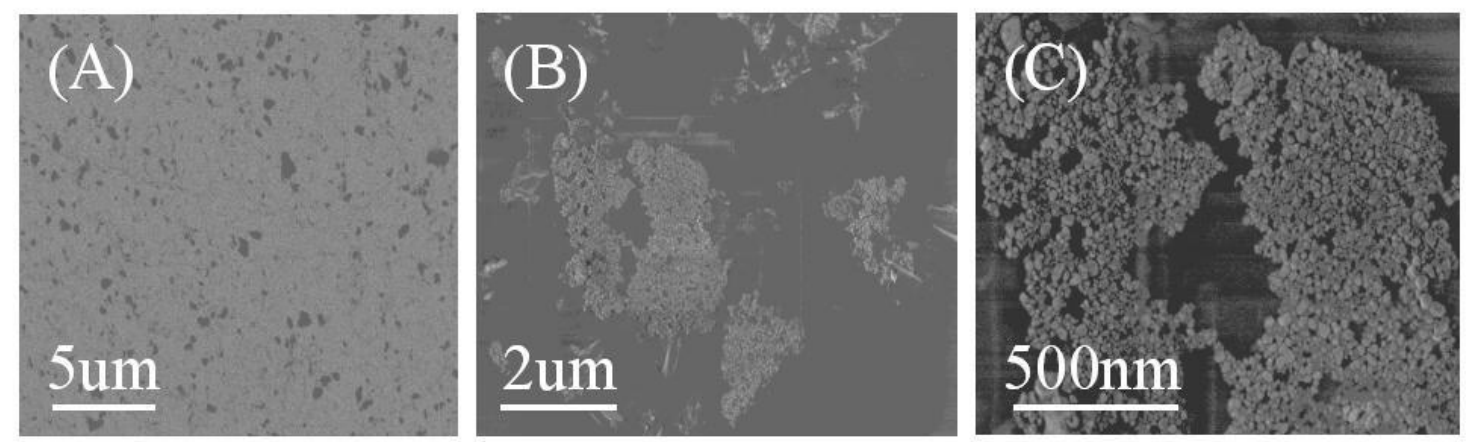

Figure 2. SEM images of bare GDE (A) and GDE after electrodeposition of Al(III) (B) and enlarge image of deposits (C). Films were electroplated at a potential of $-1.80 \mathrm{~V}$ for $120 \mathrm{~s}$ from the extractant of $10 \mu \mathrm{g} \mathrm{L}^{-1} \mathrm{Al}(\mathrm{III})$.

As shown in Figure 2A, the unmodified gold electrode surface is flat, and there are some small holes on the electrode surface. The hole increases the surface area of the electrode, which may increase 
the sensitivity of SW-ASV. Figure 2B shows the surface of a gold electrode prepared by electrodepositing the extractant of $10 \mu \mathrm{g} \mathrm{L}{ }^{-1} \mathrm{Al}(\mathrm{III})$. The surface is covered with a bulk grain particle, which should be aluminum deposits. The presence of $\mathrm{Al}$ deposits is more clearly from Figure $2 \mathrm{C}$ (enlarge image of deposits), and the diameters of the particles are between $20 \mathrm{~nm}$ and $50 \mathrm{~nm}$. Energy dispersive spectroscopy (EDS) spectra are also presented in Figure S3 (Supplementary Materials) to validate the deposition of Al. EDS analysis displays the presence of $0.94 \% \mathrm{Al}$ on the gold disk electrode surface after electrodeposition. As seen from Figure S2A (Supplementary Materials), a strong (111) diffraction peak of gold is obtained along with the other characteristic diffraction peaks (200), (220), and (311). Figure S2B (Supplementary Materials) shows the XRD patterns of a typical deposit obtained at a constant potential of $-1.8 \mathrm{~V}$ for $120 \mathrm{~s}$ in $\left[\mathrm{C}_{8} \mathrm{mim}_{[}\left[\mathrm{PF}_{6}\right]\right.$ after LPME of $10 \mu \mathrm{g} \mathrm{L} \mathrm{L}^{-1}$ aluminum on gold electrode. Compared with Figure S2A (Supplementary Materials), there is a shoulder peak at the right side of $\mathrm{Au}$ (111) diffraction peak, which might be the diffraction peak of the Au-Al alloy.

\subsection{Factor of Al(III) Accumulation in SW-ASV}

The wider aim of this study was to expand the SW-ASV to detect pmol/L level of $\mathrm{Al}(\mathrm{III})$, which few previous reports have achieved. The low concentration of $\mathrm{Al}(\mathrm{III})$ forced us to find the best efficiency of LPME and SW-ASV; moreover, saturating electrode by higher concentration of $\mathrm{Al}(\mathrm{III})$ can be avoided. Concentration of $1 \mathrm{ng} \mathrm{L}^{-1} \mathrm{Al}$ (III) was selected to optimize the experiment of LPME and SW-ASV. The effect of deposition potential on the peak current of $1 \mathrm{ng} \mathrm{L}^{-1} \mathrm{Al}(\mathrm{III})$ after LPME was studied in the potential range from -1.5 to $-2.0 \mathrm{~V}$ with $120 \mathrm{~s}$ of accumulation. Compared with the oxidation peak at $-0.8 \mathrm{~V}$, much less metal oxidized at $-1.1 \mathrm{~V}$, which was adopted in the experimental optimization and method evolution. As can be seen from Figure $3 \mathrm{~A}$, the oxidation peak of $\mathrm{Al}(\mathrm{at}-1.1 \mathrm{~V})$ were undetectable when deposition potentials were more positive than $-1.60 \mathrm{~V}$; this was because these potentials cannot initiate the reduction of $\mathrm{Al}(\mathrm{III})$. Peak currents of aluminum increased significantly after applying more negative potentials. Since no stirring was applied during SW-ASV, the rate of deposition is controlled primarily by diffusion and more negative electrolysis potential is in favor of preconcentration. However, the reproducibility of the signal of $\mathrm{Al}$ was poor at deposition potential of $-1.9 \mathrm{~V}$, which may result from the hydrogen evolution as the extractant contains a small amount of water. Based on these observations, deposition potential of $-1.8 \mathrm{~V}$ was adopted in subsequent experiments. There are two advantages of using extractant to perform SW-ASV: first, hydrogen evolution is difficult in hydrophobic ILs, which allows us to carry out the experiments within a lower potential range and sensing highly active metal ions, such as $\mathrm{K}$, $\mathrm{Na}$, etc.; second, back-extraction is unnecessary since ILs can be adopted as electrolyte in SW-ASV, which simplify the operation.

As depicted in Figure 3B, the effect of deposition time on the stripping performance for $1 \mathrm{ng} \mathrm{L}^{-1}$ of $\mathrm{Al}(\mathrm{III})$ was investigated in the range from 30 to $180 \mathrm{~s}$. The stripping peak current of $\mathrm{Al}(\mathrm{III})$ increased with the increasing of deposition time up to $120 \mathrm{~s}$, and a much wider peak was obtained for longer accumulation time. Hence, an accumulation time of $120 \mathrm{~s}$ was selected in the following measurements.

\subsection{Optimization of IL-Based LPME}

Several factors that influence the microextraction efficiency, such as concentration of the chelating agent and $\mathrm{pH}$ of the sample, were investigated.

\subsubsection{Effect of Oxine Concentration}

Oxine is a ligand widely used to form chelates with transition and heavy metal cations. The chelates are hydrophobic and can extract into organic solvents/hydrophobic ILs during LPME. The effect of oxine concentration on the current of $\mathrm{Al}(\mathrm{III})$ was studied. Figure 4 shows the peak current of aluminum increased with the increasing concentration of oxine up to $0.67 \mathrm{mmol} \mathrm{L}^{-1}$. No further increase was observed for the concentrations above this value, which indicated that $0.67 \mathrm{mmol} \mathrm{L}^{-1}$ of oxine was sufficient for total complexation. The high amount of oxine offers satisfactory $\mathrm{Al}(\mathrm{III})$ 
recovery even in the presence of large excesses of other extractable species. Therefore, $0.67 \mathrm{mmol} \mathrm{L}^{-1}$ of oxine was selected to be an optimized concentration.

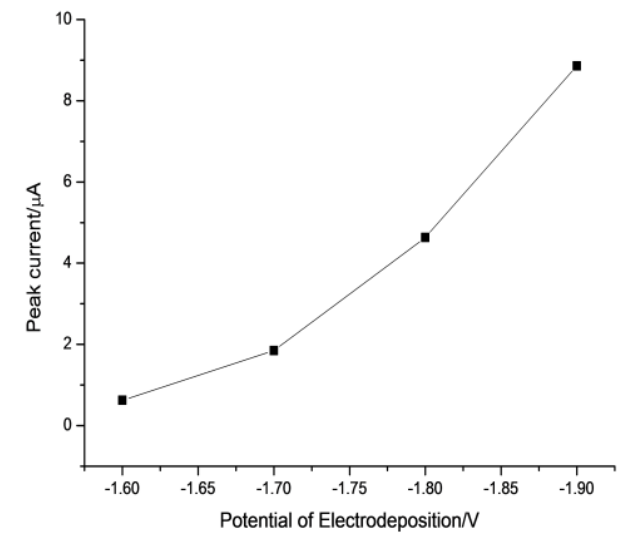

(a)

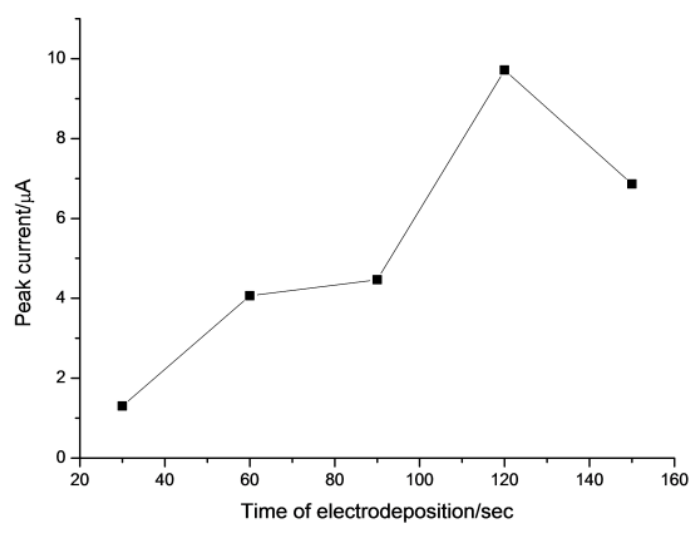

(b)

Figure 3. Effect of deposition potential (a) and deposition time (b) upon the SW-ASV response

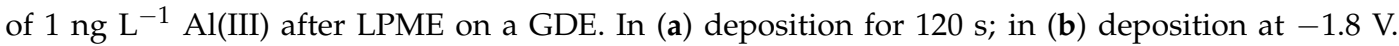
LPME conditions: centrifugation rotor speed, $4500 \mathrm{rpm}$; extraction time, $10 \mathrm{~min}$; $\mathrm{pH}$ of the sample, 6.5; sample volume, $30 \mathrm{~mL}$; concentration of oxine, $0.67 \mathrm{mmol} \mathrm{L}{ }^{-1}$; extraction $\mathrm{IL}, 150 \mu \mathrm{L}$. SW-ASV, quiet time: $10.0 \mathrm{~s}$; frequency: $20.0 \mathrm{~Hz}$; pulse amplitude: $25.0 \mathrm{mV}$; scan increment: $4.0 \mathrm{mV}$. All measurements were made in triplicate and the results were averaged.

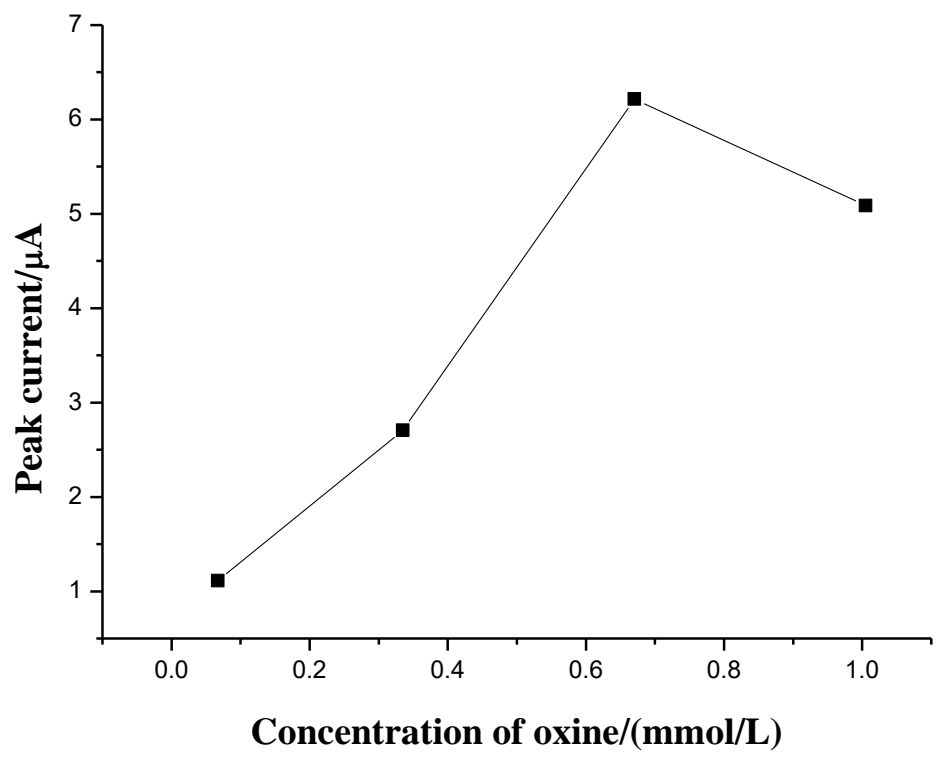

Figure 4. Effect of oxine concentration on the extraction efficiency of LPME. LPME conditions are as in Figure 3 except the concentration of oxine. Deposition potential: $-1.8 \mathrm{~V}$ (vs. Ag/ $\mathrm{AgCl}$ ); deposition time: $120 \mathrm{~s}$; quiet time: $10.0 \mathrm{~s}$; frequency: $20.0 \mathrm{~Hz}$; pulse amplitude: $25.0 \mathrm{mV}$; scan increment: $4.0 \mathrm{mV}$. All measurements were made in triplicate and the results were averaged.

\subsubsection{Effect of $\mathrm{pH}$}

The $\mathrm{pH}$ of the aqueous solution plays an important role in a metal-chelate formation and affects the subsequent LPME. In our experiment, the acetate acid buffer, which shows a fairly low level of alumimium contamination [61], was adopted as the supporting electrolytes. Figure 5 shows the effect of $\mathrm{pH}$ value of the solution on the signal intensity of $\mathrm{Al}(\mathrm{III})$. As can be seen from Figure 5, the peak of 
current increased as $\mathrm{pH}$ increased from 5.5 to 6.5 and started to decrease after $\mathrm{pH}$ 7.0. The reduced current in alkaline solution could be due to the formation of aluminum hydroxide, which decreases the amount of free $\mathrm{Al}^{3+}$ ions in sample. Hence, a $\mathrm{pH}$ of 6.5 was chosen for LPME.

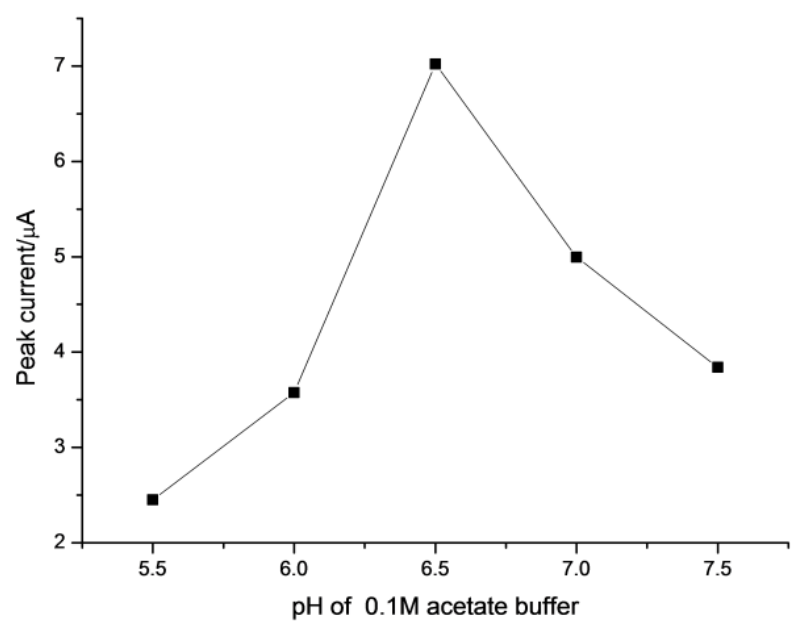

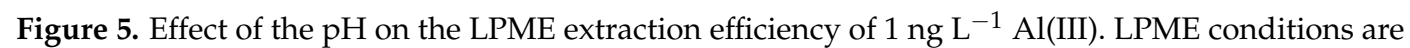
as in Figure 3 except the $\mathrm{pH}$ of the solution. The parameters of SW-ASV are same as Figure 4.

\subsection{Analytical Performance of the LPME-SW-ASV}

To evaluate the proposed method, the linearity, reproducibility, and limit of detection (LOD) were determined under optimal experimental conditions (Figure 6). Since the presence of ultratrace $\mathrm{Al}$ (III) in ultrapure water gave a blank signal, the peak current of individual standard sample was corrected manually by blank subtraction when the linear calibration cure was made. The calibration graph was linear in the range $0.1-1.2 \mathrm{ng} \mathrm{L}^{-1}$ for peak current of $\mathrm{Al}(\mathrm{III})$ at $-1.1 \mathrm{~V}$. The linear regression equation was $i_{p(\mathrm{Al}(\mathrm{III}))}(\mu \mathrm{A})=6.5214+1.3977[\mathrm{Al}(\mathrm{III})]\left(\mathrm{ng} \mathrm{L}^{-1}\right)\left(R^{2}=0.9978, n=3\right)$. The relative standard deviation (RSD) were $5.4 \%$ for $n g \mathrm{~L}^{-1} \mathrm{Al}(\mathrm{III})(n=8)$. Since it is difficult to get a water without aluminum $\left(c<0.1 \mathrm{ng} \mathrm{L}^{-1}\right)$ and no aluminum was found in ethanol, we use the mixture of oxine (dissolved in ethanol) and $\left[\mathrm{C}_{8} \mathrm{mim}\right]\left[\mathrm{PF}_{6}\right]$ as the substitute for blank solutions. A horizontal baseline from the left base of the peak was adopted. The standard deviations of the blank at $-1.1 \mathrm{~V}$ is $59 \mathrm{nA}(\mathrm{N}=25)$, from which a detection limit of $0.023 \mathrm{ng} \mathrm{L}^{-1}\left(1 \mathrm{pmol} \mathrm{L}^{-1}\right)$ (three times the standard deviations) was obtained. Ten times the standard deviation of the blank was used to evaluate the limits of quantification (LOQ). LOQ obtained was $0.076 \mathrm{ng} \mathrm{L}^{-1}$, which was close to the lower limit of linear range $\left(0.1 \mathrm{ng} \mathrm{L}^{-1}\right)$ of our method. These results proved we were not over-valuating the sensitivity of the method by using ethanol to simulate water without $\mathrm{Al}(\mathrm{III})$ and the LOD obtained is reasonable. To the best of our knowledge, it provided the lowest DL for aluminum detection (Table 1).

The effect of foreign ions on the recovery of $\mathrm{Al}(\mathrm{III})$ was studied by adding the investigated ions to a solution containing $0.1 \mathrm{ng} \mathrm{L}^{-1}$ of $\mathrm{Al}(\mathrm{III})$, and the recommended procedure was followed. The tolerance limits-defined as the highest amount of foreign ions that changed the peak current of $\mathrm{Al}$ (III) by five percent-were presented in Table 2. The interference experiment will stop when the interferential concentration is 5000-fold higher than that of $\mathrm{Al}$ (III). As can be seen from the Table 2, the following ions, such as $\mathrm{K}^{+}, \mathrm{Na}^{+}, \mathrm{Zn}^{2+}, \mathrm{Pb}^{2+}, \mathrm{Cd}^{2+}$ and $\mathrm{Cr}^{3+}$, had little effect on the determination of aluminum(III). Compared with the previous reports using AdSV detection, the interference from the common metal ions remarkably decreased [15,22]. This can be attributed to the following factors: the metal ions, which cannot form a metal ion-oxine complex and have the poor solubility in $\left[\mathrm{C}_{8} \mathrm{mim}\right][\mathrm{PF} 6]$, would be eliminated during LPME; moreover, the oxidation peak of the most metals, such as $\mathrm{Zn}, \mathrm{Pb}$, and $\mathrm{Cd}$, is more positive than that of $\mathrm{Al}$, and can be easily discriminated from Al during SW-ASV analysis. 


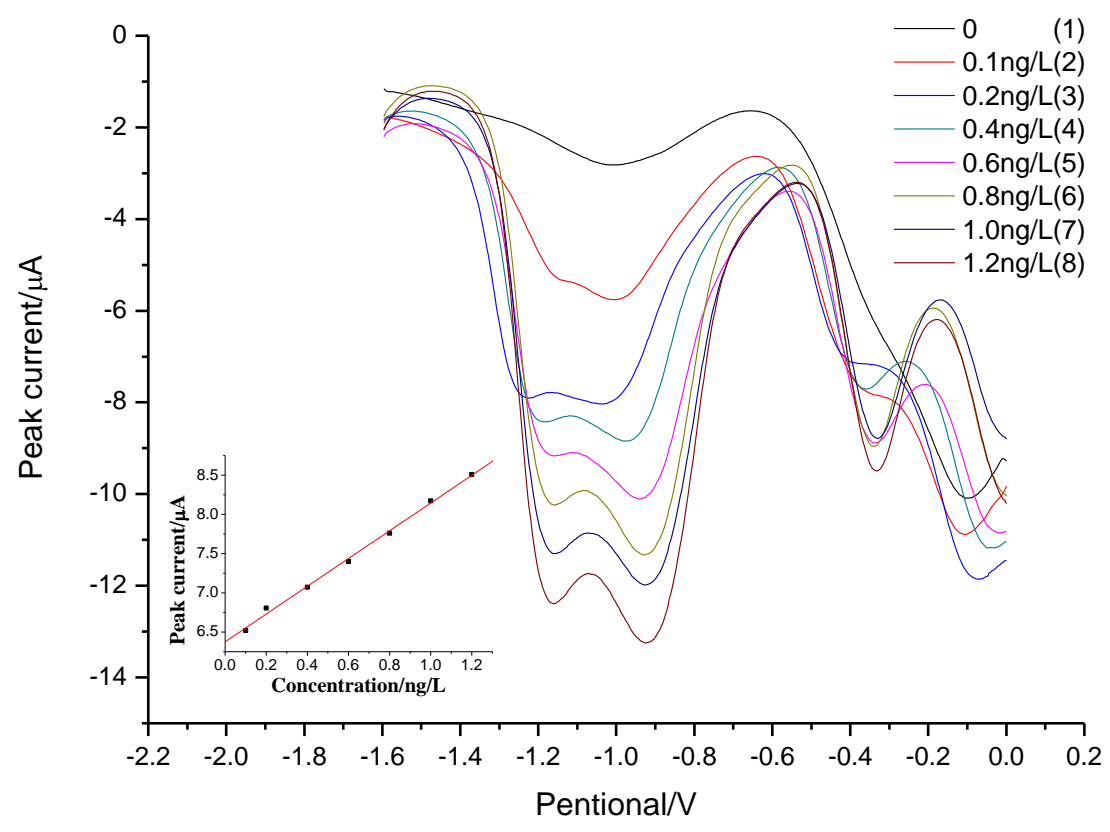

Figure 6. LPME-SW-ASV of $\mathrm{Al}(\mathrm{III})$ with different concentrations (from 0.1 to $1.2 \mathrm{ng} \mathrm{L}^{-1}$ ). Inset: Corresponding calibration plots. LPME conditions are same as Figure 3. The parameters of SW-ASV are same as Figure 4.

Table 1. Comparison of the proposed method with other electrochemical techniques for the determination of $\mathrm{Al}(\mathrm{III})$.

\begin{tabular}{|c|c|c|c|c|c|c|c|}
\hline Technique & Modification/Chelator & LOD (nM) & Reference & Technique & Modification/Chelator & LOD (nM) & Reference \\
\hline \multicolumn{4}{|c|}{ Mercury Drop Electrodes } & \multicolumn{4}{|c|}{ Glass Carbon Electrode } \\
\hline AdSV & SVRS & 76 & [16] & DPV & Alizarin (graphene on E) & 90 & [35] \\
\hline AdSV & cupferron & 50 & [30] & AdSV & Cupferron (Bismuth film GCE) & 18 & [32] \\
\hline AdSV & oxine & 85 & [25] & DPV & alizarin red $\mathrm{S}$ on $\mathrm{E}$ & 80 & [36] \\
\hline AdSV & dithiooxamide & 0.4 & [27] & Amperometry & DASA & 370 & [24] \\
\hline SW-AdSV & oxine & 0.7 & [26] & DPV & catechol & 1.4 & [12] \\
\hline AdSV & SVRS & 67 & [17] & DPV & L-dopa & 890 & [38] \\
\hline AdSV & pyrogallol red & 37 & [28] & DPV & dopamine & 140 & [39] \\
\hline AdSV & DASA & 30 & [20] & DPV & L-dopa & 76 & [40] \\
\hline LSV & norepinephrine & 1800 & [37] & AdSV & TMAC & 0.05 & [10] \\
\hline AdSV & SVRS & 52 & [18] & \multicolumn{4}{|c|}{ Carbon electrode } \\
\hline AdSV & SVRS & 3.8 & [15] & ASV & Zinc & 296 & [8] \\
\hline $\mathrm{AdCP}$ & PCV & 8 & [14] & Potentiometry & AlMCM- 41 on E & 460 & [11] \\
\hline AdSV & morine & 4.07 & [29] & \multicolumn{4}{|c|}{ Gold nanoparticles modified carbon electrode } \\
\hline AdSV & Alizarin S & 25 & [33] & Amperometry & AChE on $\mathrm{E}$ & 2100 & [42] \\
\hline DP-AdSV & DASA & 7.4 & [21] & Amperometry & $\alpha$-chymotrypsin on E & 3300 & [43] \\
\hline AdSV & DASA & 1.8 & [22] & \multicolumn{4}{|c|}{ Pyrolytic graphite electrode } \\
\hline \multicolumn{4}{|c|}{ Mercury film modified glass carbon electrode } & DPV & PCV on $\mathrm{E}$ & 5 & [13] \\
\hline SWV & Alizarin R & 10 & [34] & Voltammetry & SVRS & 370 & [19] \\
\hline AdSV & DASA & 1000 & [23] & \multicolumn{4}{|c|}{ Gold electrode } \\
\hline LSV & cupferron & 18 & [31] & EIS & SHQ & 0.008 & [45] \\
\hline \multicolumn{4}{|c|}{ Bismuth film on Pt electrode } & SW-ASV & Oxine & 0.001 & This work \\
\hline AdSV & EBBR & 0.56 & [41] & & & & \\
\hline
\end{tabular}

AdCP: Adsorption Chronopotentiometry, DPV: differential pulse voltammetry, EIS: electrochemical impedance spectroscopy, LSV: linear scan voltammetry, SWV: square wave voltammetry; AChE: Acetylcholinesterase, DASA: 1,2-dihydroxyanthraquinone-3-sulfonic acid, EBBR: Eriochrome blue black R; PCV: pyrocatechol violet, SVRS: solochrome violet RS, TMAC: tetramethylammonium chloride.

Table 2. Tolerance limits of foreign ions in the determination of $0.1 \mathrm{ng} \mathrm{L}^{-1} \mathrm{Al}^{3+}$. All measurements were made in triplicate and the results averaged.

\begin{tabular}{ccc}
\hline Element & Tolerance Limit $\left(\right.$ ng L $\left.^{-1}\right)$ & Interferent: Al Ratio \\
\hline $\mathrm{K}^{+}, \mathrm{Na}^{+}$ & 500 & 5000 \\
$\mathrm{Cd}^{2+}, \mathrm{Pb}^{2+}, \mathrm{Cr}^{3+}, \mathrm{Zn}^{2+}$ & 100 & 1000 \\
$\mathrm{Ca}^{2+}, \mathrm{Cu}^{2+}, \mathrm{Sn}^{2+}$ & 10 & 100 \\
\hline
\end{tabular}




\subsection{Analytical Application to Commercial Distilled Water}

The method was applied to detecting $\mathrm{Al}(\mathrm{III})$ in a commercial distilled water. Since the amount of $\mathrm{Al}(\mathrm{III})$ in sample is beyond the upper limit of the method, $0.3 \mathrm{~mL}$ of a commercial distilled water was used instead of $30 \mathrm{~mL}$. As depicted in Figure 7, the regression equation was $i_{p}(\mathrm{Al}(\mathrm{III}))(\mu \mathrm{A})=1.833+0.536[\mathrm{Al}(\mathrm{III})]\left(\mathrm{ng} \mathrm{L}^{-1}\right)\left(R^{2}=0.9948\right)$. The concentration of $\mathrm{Al}(\mathrm{III})$, evaluating by extrapolation, was $3.42 \pm 0.63 \mathrm{ng} \mathrm{L}^{-1}$. The recoveries of aluminum were between $91.0 \%$ and $109 \%$ for spiked samples. The ICP-MS yielded a concentration of $\mathrm{Al}(\mathrm{III})$ equal to $4.2 \pm 1.2 \mathrm{ng} \mathrm{L}^{-1}$. The present method was in agreement with those determined by ICP-MS, which proves the accuracy of the proposed methodology.

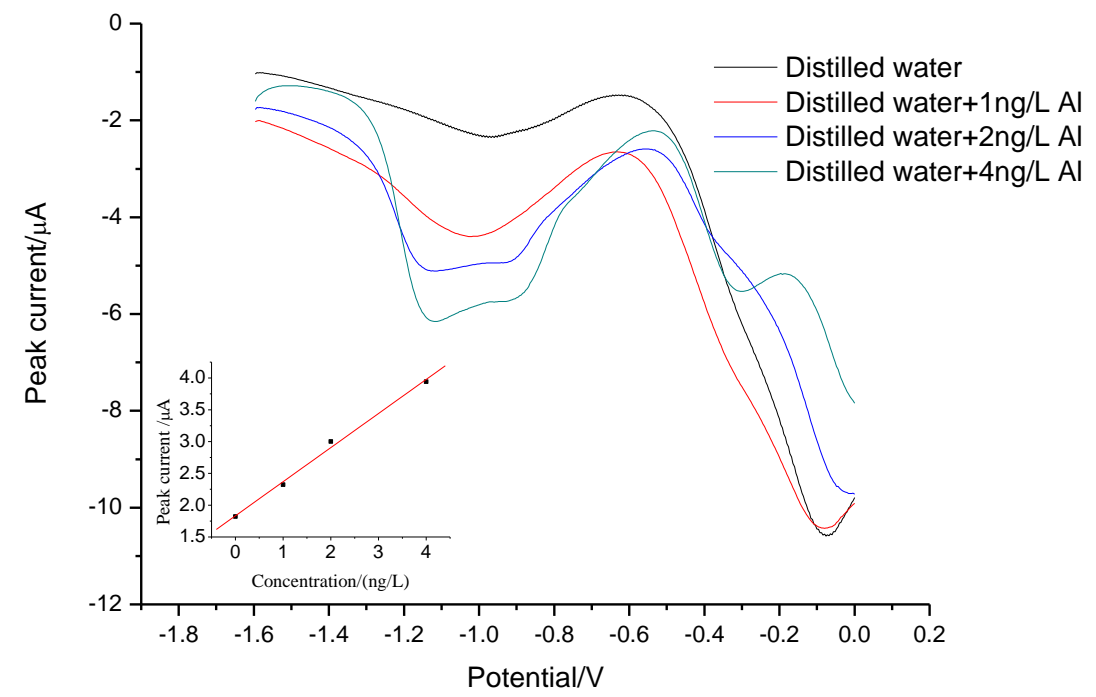

Figure 7. LPME-SW-ASV of Al(III) in commercial distilled water sample with standard addition method. The inset shows the corresponding standard plot. LPME conditions are same as Figure 3. The parameters of SW-ASV are same as Figure 4.

\section{Conclusions}

Liquid phase microextraction coupled with anodic stripping voltammetry used to determine ultra-trace aluminum in aqueous samples was reported for the first time. It has the following important merits: (a) Our method provides better selectivity for $\mathrm{Al}(\mathrm{III})$ due to the selective extraction of oxine-complexes in water samples during LPME and the chemical resolution of SW-ASV; (b) The LOD attains as low as $1 \mathrm{pmol} \mathrm{L}^{-1}$, which reaches the lowest report for $\mathrm{Al}(\mathrm{III})$ detection using electroanalytical techniques; moreover, the lower limit of linear range $\left(0.1 \mathrm{ng} \mathrm{L}^{-1}\right)$ in our experiment was even lower than the lowest LOD for $\mathrm{Al}(\mathrm{III})$ reported using electrochemical detection; (c) Reusable ionic liquid and non-mercury electrode was adopted in our experiment, and the method is environment friendly; (d) The method can be applied to analyze other metal ions with high electronegativity by choosing appropriate chelating agent, which provides an attractive alternative to cathodic adsorptive stripping voltammetry.

Supplementary Materials: The following are available online at http:/ / www.mdpi.com/1424-8220/18/5/1503/ s1, Figure S1: Image of microliter voltammetric cell from top view (A) and side view (B). Figure S2: XRD patterns of bare gold disk electrode (lower curve) and the deposit obtained potentiostatically at $-1.8 \mathrm{~V}$ for $120 \mathrm{~s}$ after IL-based LPME of $10 \mu \mathrm{g} \mathrm{L}{ }^{-1} \mathrm{Al}(\mathrm{III})$ on the gold substrate (upper curve). Figure S3: Energy-dispersive X-ray spectroscopy (EDX) analysis of Al deposition on GDE.

Author Contributions: H.F. and C.L. conceived and designed the experiments; L.Z. and J.L. performed the experiments, these authors contributed equally to this work; the SEM experiment was done by X.S.; H.F., X.W. and B.N. wrote the paper. 
Funding: This research was funded by National Natural Science Foundation of China (Nos. 21275165, 21275166, 21275167), Key Laboratory of Analytical Chemistry for Biology and Medicine (Ministry of Education) (No. ACBM2012005), the National Natural Science Foundation of Hubei Province (No. 2014CFA025) and the Natural Science Foundation of South-Central University for Nationalities (No. PCZY12020).

Conflicts of Interest: The authors declare no conflict of interest.

\section{References}

1. Evans, E.H.; Pisonero, J.; Smith, C.M.M.; Taylor, R.N. Atomic spectrometry update: Review of advances in atomic spectrometry and related techniques. J. Anal. At. Spectrom. 2017, 32, 869-889. [CrossRef]

2. Donati, G.L.; Amais, R.S.; Williams, C.B. Recent advances in inductively coupled plasma optical emission spectrometry. J. Anal. At. Spectrom. 2017, 32, 1283-1296. [CrossRef]

3. Quang, D.T.; Kim, J.S. Fluoro- and chromogenic chemodosimeters for heavy metal ion detection in solution and biospecimens. Chem. Rev. 2010, 110, 6280-6301. [CrossRef] [PubMed]

4. Wang, H.; He, M.; Chen, B.; Hu, B. Advances in ICP-MS-based techniques for trace elements and their species analysis in cells. J. Anal. At. Spectrom. 2017, 32, 1650-1659. [CrossRef]

5. Batchelor-McAuley, C.; Dickinson, E.J.F.; Rees, N.V.; Toghill, K.E.; Compton, R.G. New electrochemical methods. Anal. Chem. 2012, 84, 669-684. [CrossRef] [PubMed]

6. Walcarius, A. Recent Trends on Electrochemical Sensors Based on Ordered Mesoporous Carbon. Sensors 2017, 17, 1863. [CrossRef] [PubMed]

7. Willard, H.H.; Deani, J.A. Polarographic Determination of Aluminum. Anal. Chem. 1950, 22, $1264-1267$. [CrossRef]

8. Dilleen, J.W.; Birch, B.J.; Haggett, B.G.D. Electrochemical detection of aluminium using single-use sensors. Anal. Commun. 1999, 36, 363-365. [CrossRef]

9. Bi, S.; Yang, X.D.; Zhang, F.P.; Wang, X.L.; Zou, G.W. Analytical methodologies for aluminium speciation in environmental and biological samples-A review. Fresenius J. Anal. Chem. 2001, 370, 984-996. [CrossRef] [PubMed]

10. Abo El-Maali, N.; Abd El-Hady, D.; Abd El-Hamid, M.; Seliem, M.M. Use of adsorptive stripping voltammetry at the glassy carbon electrode for the simultaneous determination of magnesium(II) and aluminium(III). Application to some industrial samples. Anal. Chim. Acta 2000, 417, 67-75. [CrossRef]

11. Arvand, M.; Kermanian, M. Potentiometric determination of aluminum in foods, pharmaceuticals, and alloys by AlMCM-41-modified carbon paste electrode. Food Anal. Methods 2013, 6, 578-586. [CrossRef]

12. Liu, J.; Bi, S.; Yang, L.; Gu, X.; Ma, P.; Gan, N.; Wang, X.; Long, X.; Zhang, F. Speciation analysis of aluminium(III) in natural waters and biological fluids by complexing with various catechols followed by differential pulse voltammetry detection. Analyst 2002, 127, 1657-1665. [CrossRef] [PubMed]

13. Chen, G.; Bi, S.; Dai, L.; Cao, M.; Chen, Y.; Wang, X. Indirect differential pulase voltammetric determination of aluminum by a pyrocatechol violet modified electrode. Anal. Lett. 1999, 32, 865-883. [CrossRef]

14. Wang, X.; Bi, S.; Gan, N.; Wei, Z. Aluminum speciation with adsorptive Pyrocatechol Violet-Al(III) complex by derivative adsorption chronopotentiometry. Electroanalysis 2001, 13, 1279-1286. [CrossRef]

15. Wang, X.; Lei, J.; Bi, S.; Gan, N.; Wei, Z. Determination of the speciation of aluminum(III) in natural waters by adsorption stripping voltammetry and complexation with $\mathrm{Al}^{\mathrm{III}}$-solochrome violet RS. Anal. Chim. Acta 2001, 449, 35-44. [CrossRef]

16. Muratt, D.T.; de Carvalho, L.M.; Viana, C.; do Nascimento, P.C.; Reis, G.; Dal Molin, T.R.; Grassmann, C.; Smidt, G.; Koschinsky, A. Sequential determination of 13 elements in complex matrices by stripping voltammetry with mixed complexing electrolytes. Electroanalysis 2015, 27, 1625-1635. [CrossRef]

17. Nascimento, P.C.; Del-Fabro, L.D.; Bohrer, D.; de Carvalho, L.M.; Rosa, M.B.; Noremberg, S.M. Al(III) and $\mathrm{Fe}(\mathrm{III})$ balance in hemodialysis treatment assessed via fluid analysis by adsorptive stripping voltammetry and UV sample digestion. Electroanalysis 2008, 20, 1078-1084. [CrossRef]

18. Locatelli, C. Simultaneous determination of aluminum and iron in high salt content matrices by sdsorptive stripping voltammetry. Application to dialysis fluids. Electroanalysis 2003, 15, 1397-1402. [CrossRef]

19. Florence, T.M.; Miller, F.J.; Zittel, H.E. Voltammetric determination of aluminum by oxidation of its solochrome violet RS complex at the rotated pyrolytic graphite electrode. Anal. Chem. 1966, 38, 1065-1067. [CrossRef] 
20. De Carvalho, L.M.; do Nascimento, P.C.; Bohrer, D.; Stefanello, R.; Bertagnolli, D. Determination of aluminum as contaminant in dialysis concentrates by adsorptive cathodic stripping voltammetry. Anal. Chim. Acta 2005, 546, 79-84. [CrossRef] [PubMed]

21. Cullen, M.; Lancashire, S. Determination of low concentrations of nickel and aluminium in membrane electrolyser liquors. Analyst 1996, 121, 75-78. [CrossRef]

22. Hernández-Brito, J.J.; Gelado-Caballero, M.D.; Pérez-Peiia, J.; Herrera-Melián, J.A. Fast determination of aluminium reactive to 1,2-dihydroxyanthraquinone-3-sulfonic Acid in sea-water. Analyst 1994, 119, 1593-1597. [CrossRef]

23. Thomas, S.D.; Davey, D.E.; Mulcahy, D.E.; Chow, C.W.K. Determination of aluminum by adsorptive cathodic stripping voltammetry with 1,2-dihydroxyanthraquinone-3-sulfonic acid (DASA): Effect of thin mercury film electrode. Electroanalysis 2006, 18, 2257-2262. [CrossRef]

24. Chow, C.W.K.; Thomas, S.D.; Davey, D.E.; Mulcahy, D.E.; Drikas, M. Development of an on-line electrochemical analyser for trace level aluminium. Anal. Chim. Acta 2003, 499, 173-181. [CrossRef]

25. Santos, L.B.; de Souza, M.T.F.; Paulino, A.T.; Garcia, E.E.; Nogami, E.M.; Garcia, J.C.; de Souza, N.E. Determination of aluminum in botanical samples by adsorptive cathodic stripping voltammetry as Al-8-hydroxyquinoline complex. Microchem. J. 2014, 112, 50-55. [CrossRef]

26. Beltagi, A.M.; Ghoneim, M.M. Simultaneous determination of trace aluminum (III), copper (II) and cadmium (II) in water samples by square-wave adsorptive cathodic stripping voltammetry in the presence of oxine. J. Appl. Electrochem. 2009, 39, 627-636. [CrossRef]

27. Abbasi, S.; Bahiraei, A.; Farmany, A. Quantification of sub-nanomolar levels of aluminum by adsorptive stripping voltammetry using rubeanic acid as a selective chelating agent. Electroanalysis 2010, 22, 1889-1893. [CrossRef]

28. Arancibia, V.; Muñoz, C. Determination of aluminium in water samples by adsorptive cathodic stripping voltammetry in the presence of pyrogallol red and a quaternary ammonium salt. Talanta 2007, 73, 546-552. [CrossRef] [PubMed]

29. El-Maali, N.A.; Temerka, Y.M.; El-Azizb, M.S.A. Application of stripping voltammetry at a static mercury drop electrode for the determination of aluminium and iron in Portland cement. Anal. Chim. Acta 1997, 353, 313-318. [CrossRef]

30. Magnier, A.; Fekete, V.; VanLoco, J.; Bolle, F.; Elskens, M. Speciation study of aluminiumin beverages by competitive ligand exchange-adsorptive stripping voltammetry. Talanta 2014, 122, 30-35. [CrossRef] [PubMed]

31. Balbo, A.L.; Dall'Orto, V.C.; Sobral, S.; Rezzano, I. Linear scan stripping voltammetry at glass-carbon based thin mercury film electrodes for determination of trace aluminium in dialysis fluids. Anal. Lett. 1998, 31, 2717-2728. [CrossRef]

32. Kefala, G.; Economou, A.; Sofoniou, M. Determination of trace aluminium by adsorptive stripping voltammetry on a preplated bismuth-film electrode in the presence of cupferron. Talanta 2006, 68, 1013-1019. [CrossRef] [PubMed]

33. Opydo, J. Determination of aluminium in tree samples by cathodic adsorptive stripping voltammetry. Talanta 1997, 44, 1081-1086. [CrossRef]

34. Paulino, A.T.; Vargas, A.M.M.; Santos, L.B.; Nozaki, J.; Muniz, E.C.; Tambourgi, E.B. Square wave voltammetry in the determination of $\mathrm{Ni}^{2+}$ and $\mathrm{Al}^{3+}$ in biological samples. Anal. Sci. 2008, 24, 1443-1447. [CrossRef] [PubMed]

35. Tang, Y.; Sun, C.; Yang, X.; Yang, X.; Shen, R.F. Graphene modified glassy carbon electrode for determination of trace aluminium(III) in biological samples. Int. J. Electrochem. Sci. 2013, 8, 4194-4205.

36. Di, J.; Bi, S.; Yang, T.; Zhang, M. Voltammetric determination of aluminum(III) using a reagentless sensor fabricated by sol-gel process. Sens. Actuators B 2004, 99, 468-473. [CrossRef]

37. Zhang, F.; Ji, M.; Xu, Q.; Yang, L.; Bi, S. Linear scan voltammetric indirect determination of $\mathrm{Al}^{\mathrm{III}}$ by the catalytic cathodic response of norepinephrine at the hanging mercury drop electrode. J. Inorg. Biochem. 2005, 99, 1756-1761. [CrossRef] [PubMed]

38. Zhang, F.; Bi, S.; Li, H.; Chen, Y.; Dai, L. Application of L-Dopa as an electroactive ligand for indirect determination of aluminum in biological samples by differential pulse voltammetry. Electroanalysis 2001, 13, 1054-1058. [CrossRef] 
39. Zhang, F.; Yang, L.; Bi, S.; Liu, J.; Liu, F.; Wang, X.; Yang, X.; Gan, N.; Yu, T.; Hu, J.; et al. Neurotransmitter dopamine applied in electrochemical determination of aluminum in drinking waters and biological samples. J. Inorg. Biochem. 2001, 87, 105-113. [CrossRef]

40. Zhang, F.; Bi, S.; Zhang, J.; Bian, N.; Liu, F.; Yang, Y. Differential pulse voltammetric indirect determination of aluminium in drinking waters, blood, urine, hair, and medicament samples using L-dopa under alkaline conditions. Analyst 2000, 125, 1299-1302. [CrossRef] [PubMed]

41. Wang, H.; Yu, Z.; Wang, Z.; Hao, H.; Chen, Y.; Wan, P. Preparation of a preplated bismuth film on Pt electrode and its application for determination of trace aluminum(III) by adsorptive stripping voltammetry. Electroanalysis 2011, 23, 1095-1099. [CrossRef]

42. Barquero-Quirós, M.; Domínguez-Renedo, O.; Alonso-Lomillo, M.A.; Arcos-Martínez, M.J. Acetylcholinesterase inhibition-based biosensor for aluminum(III) chronoamperometric determination in aqueous media. Sensors 2014, 14, 8203-8216. [CrossRef] [PubMed]

43. Barquero-Quirós, M.; Domínguez-Renedo, O.; Alonso-Lomillo, M.A.; Arcos-Martínez, M.J. Biosensor for aluminium(III) based on its inhibition of $\alpha$-chymotrypsin immobilized on a screen-printed carbon electrode modified with gold nanoparticles. Microchim. Acta 2012, 179, 65-70. [CrossRef]

44. Barquero-Quirós, M.; Arcos-Martínez, M.J. Effect of Nanoparticles on Modified Screen Printed Inhibition Superoxide Dismutase Electrodes for Aluminum. Sensors 2016, 16, 1588. [CrossRef] [PubMed]

45. Shervedani, R.K.; Rezvaninia, Z.; Sabzyan, H.; Boeini, H.Z. Characterization of gold-thiol-8-hydroxyquinoline self-assembled monolayers for selective recognition of aluminum ion using voltammetry and electrochemical impedance spectroscopy. Anal. Chim. Acta 2014, 825, 34-41. [CrossRef] [PubMed]

46. Osada, I.; de Vries, H.; Scrosati, B.; Passerini, S. Ionic-Liquid-Based Polymer Electrolytes for Battery Applications. Angew. Chem. Int. Ed. 2016, 55, 500-513. [CrossRef] [PubMed]

47. Watanabe, M.; Thomas, M.L.; Zhang, S.; Ueno, K.; Yasuda, T.; Dokko, K. Application of Ionic Liquids to Energy Storage and Conversion Materials and Devices. Chem. Rev. 2017, 117, 7190-7239. [CrossRef] [PubMed]

48. Wen, R.; Rahn, B.; Magnussen, O.M. Potential-dependent adlayer structure and dynamics at the ionic liquid/Au(111) interface: A molecular-scale in situ video-STM study. Angew. Chem. Int. Ed. 2015, 54, 6062-6066. [CrossRef] [PubMed]

49. Hallett, J.P.; Welton, T. Room-temperature ionic liquids: Solvents for synthesis and catalysis. 2. Chem. Rev. 2011, 111, 3508-3576. [CrossRef] [PubMed]

50. Egorova, K.S.; Gordeev, E.G.; Ananikov, V.P. Biological Activity of Ionic Liquids and Their Application in Pharmaceutics and Medicine. Chem. Rev. 2017, 117, 7132-7189. [CrossRef] [PubMed]

51. Falola, B.D.; Suni, I.I. Low temperature electrochemical deposition of highly active elements. Curr. Opin. Solid State Mater. Sci. 2015, 19, 77-84. [CrossRef]

52. Martinis, E.M.; Berton, P.; Wuilloud, R.G. Ionic liquid-based microextraction techniques for trace-element analysis. Trends Anal. Chem. 2014, 60, 54-70. [CrossRef]

53. Martinis, E.M.; Berton, P.; Monasterio, R.P.; Wuilloud, R.G. Emerging ionic liquid-based techniques for total-metal and metal-speciation analysis. Trends Anal. Chem. 2010, 29, 1184-1201. [CrossRef]

54. Berton, P.; Martinis, E.M.; Martinezc, L.D.; Wuilloud, R.G. Room temperature ionic liquid-based microextraction for vanadium species separation and determination in water samples by electrothermal atomic absorption spectrometry. Anal. Chim. Acta 2009, 640, 40-46. [CrossRef] [PubMed]

55. Reyna-González, J.M.; Torriero, A.A.J.; Siriwardana, A.I.; Burgar, I.M.; Bond, A.M. Extraction of copper(II) ions from aqueous solutions with a methimazole-based ionic liquid. Anal. Chem. 2010, 82, 7691-7698. [CrossRef] [PubMed]

56. Abdolmohammad-Zadeh, H.; Sadeghi, G.H. Combination of ionic liquid-based dispersive liquid-liquid micro-extraction with stopped-flow spectrofluorometry for the pre-concentration and determination of aluminum in natural waters, fruit juice and food samples. Talanta 2010, 81, 778-785. [CrossRef] [PubMed]

57. Chen, P.Y.; Hussey, C.L. Electrochemistry of ionophore-coordinated Cs and Sr ions in the tri-1butylmethylammonium bis((trifluoromethyl)sulfonyl)imide ionic liquid. Electrochim. Acta 2005, 50, 2533-2540. [CrossRef]

58. Kamio, A.; Nagaosa, Y. 1-Butyl-3-methylimidazolium Hexafluorophosphate Ionic Liquid as a New Solvent for the Determination of Lead(II) and Cadmium(II) by Anodic Stripping Voltammetry after Extraction of the Iodide Complexes. Anal. Sci. 2008, 24, 1363-1367. [CrossRef] [PubMed] 
59. Sbartai, A.; Namour, P.; Sarrut, N.; Krejči, J.; Kucerova, R.; Hamlaoui, M.L.; Jaffrezic-Renault, N. Direct detection of lead in RTIL using DPASV on BDD film microcells and determination of concentration factor after extraction from aqueous samples. J. Electroanal. Chem. 2012, 686, 58-62. [CrossRef]

60. Li, Z.; Xia, S.; Wang, J.; Bian, C.; Tong, J. Determination of trace mercury in water based on $\mathrm{N}$-octylpyridiniumionic liquids preconcentration and stripping voltammetry. J. Hazard. Mater. 2016, 301, 206-213. [CrossRef] [PubMed]

61. Buratti, M.; Valla, C.; Pellegrino, O.; Rubino, F.M.; Colombi, A. Aluminum determination in biological fluids and dialysis concentrates via chelation with 8-hydroxyquinoline and solvent extraction/fluorimetry. Anal. Biochem. 2006, 353, 63-68. [CrossRef] [PubMed]

(C) 2018 by the authors. Licensee MDPI, Basel, Switzerland. This article is an open access article distributed under the terms and conditions of the Creative Commons Attribution (CC BY) license (http:/ / creativecommons.org/licenses/by/4.0/). 